\title{
A Study on Curriculum Reform of Business English in Application-oriented Universities in the New Era
}

\author{
Min $\mathrm{Xu}^{1,{ }^{1 *}}$ Chuandong Zhang ${ }^{2}$ \\ ${ }^{1}$ Wuchang Shouyi University, Wuhan, Hubei, China \\ ${ }^{2}$ China Ship Design \& Development Centre, Wuhan, Hubei, China \\ *Corresponding author. Email: $93319643 @ q q . c o m$
}

\begin{abstract}
In the new situation, employers have put forward new requirements on the ability of business English majors. Through analyzing the questionnaire survey data, it is indicated that there are problems of the curriculum setting of Business English Specialty in application-oriented colleges and universities, such as unscientific curriculum construction with serious homogeneity, imperfect practical teaching system, relatively weak faculty, insufficiently deep cooperation between schools and enterprises, etc. Based on the study and practice, a lot of solutions are put forward: the establishment of "progressive and modularization" curriculum system, modularization of skill courses, promotion of learning through competition, integration of courses and certificates, school-enterprise cooperation. In these ways, it makes the Business English talent cultivation distinctive and effective.
\end{abstract}

Keywords: Curriculum, Application-oriented, Module, Cultivation.

\section{THE BACKGROUND AND SIGNIFICANCE OF THE RESEARCH}

China's foreign trade situation has undergone great changes since the new century. As the modern computer network develops, more complex and diversified aspects and factors are involved in the foreign trade situation. Different from the previous simple economic activities in foreign trade, the society puts forward higher requirements for modern business English talents.

More than 403 business English undergraduate colleges have been set up so far in China, and students' professional educational quality has already been improved gradually [1]. However, there is a small, uneven distribution of graduates every year, and the limited number graduates is far from satisfying the continuing market demand for high-level, compound applied business English talents. The cultivation scale of business English talents still needs to expanded and their improved professional quality is also called for.

\section{THE EMPLOYER'S REQUIREMENTS FOR BUSINESS ENGLISH MAJORS}

Based on the interviews with employers, the interviewees generally believe that schools should cultivate students' core abilities: the communication skills, the strong practical ability, the mastery and utility of professional knowledge. They propose a lot of constructive comments and suggestions. 1) Improve the students' overall qualities; 2)Cultivate students with good ideology and morality; 3) Students are required to lay a sound foundation of English language knowledge with fluent spoken English and strong business practice ability; 4) Schools should pay attention to teaching quality; 5) Motivate students to participate in social practice and conduct practical education; 6) Train students' written expression and translation skills; 7) Encourage students to enhance their self-confidence; 8) Cultivate students' social communication ability and improve their overall image.

According to the interview, the school is required to cultivate students to acquire knowledge with strong practicability and pertinence, foster students' English language skills, especially spoken English skills. Students also need to have abundant business experiences and master business communication skills. It puts forward the demand that the school should improve teaching quality and cultivate the students' comprehensive qualities. These findings should arouse our great attention and need to be adjusted and strengthened in Business English teaching in the future. They are also the important basis for the development and reform of Business English curriculum with valuable and practical references. 


\section{THE CURRENT SITUATION AND PROBLEMS OF BUSINESS ENGLISH CURRICULUM SETTING IN APPLICATION-ORIENTED COLLEGES}

Based on the questionnaire results in different application-oriented colleges and universities, the following common problems are found:

\subsection{Unscientific Curriculum Construction With Serious Homogeneity}

The curriculum setting of business English major in most colleges mainly refers to the curriculum setting of relevant majors in the same type of schools and lacks its own curriculum system. In particular, independent colleges and private colleges face a lot of discomfort in this course system. For example, students' acceptance ability cannot adapt to the course content, and the course structure and implementation method cannot meet the employers' demand for business English talents. The curriculum system of business English major in most independent colleges or private colleges is still short of contents concerning the national conditions, culture and business etiquette of the countries along the "One Belt And One Road". The course knowledge of ecommerce and cross-border e-commerce is also relatively poor.

\subsection{Imperfect Practical Teaching System}

Business English, as a new major since 2008, its practical teaching system is not perfect. At present, private colleges and universities have made a lot of exploration on the practical teaching reform of business English, but the problem of insufficient practical teaching is still widespread. First of all, its professional curriculum practice teaching has not formed a mature and scientific system. Due to the lack of funds and management of student apprenticeship, most private colleges and universities have not implemented the regular teaching activities. In terms of professional practice, due to the limited number of interns admitted by the internship base each year, the internship places are too scattered, which makes it difficult for school teachers to guide and manage interns, so the effectiveness of the internship is greatly reduced.

\subsection{Relatively Weak Faculty}

Many Business English teachers in colleges and universities have not received systematic professional training in business, and their professional knowledge of business is very limited. Although they have some basic knowledge of English language and culture, they still lack knowledge of international business and culture. Some teachers are introduced from the economic department or enterprises, and their English pragmatic ability and teaching ability are relatively deficient. In addition, due to the consideration of operating cost saving and other aspects, private colleges and universities do not attach much importance to the construction of teaching staff and their support is weak.

\subsection{Insufficiently Deep Cooperation Between Schools And Enterprises}

The cooperation between business English majors in colleges and universities and local enterprises, especially multinational enterprises, is not deep enough. First, there is a lack of cooperation in professional setting. In the setting of Business English course modules, there is no flexible adjustment according to the needs of local economic development. Second, in the implementing process of the course, the lack of industry experts' and entrepreneurs' participation leads to the small proportion of dual-qualified teachers. Third, it is the lack of teaching system arrangement of schoolenterprise cooperation. Due to the heavy teaching tasks and the lack of relevant systems in schools to encourage teachers to deeply participate in school-enterprise cooperation projects, some school-enterprise cooperation activities have often not been undertaken. In particular, the school-enterprise cooperation fields of Business English major in private colleges still needs to be explored.

\section{THE TRAINING OBJECTIVES OF BUSINESS ENGLISH MAJORS IN APPLICATION-ORIENTED COLLEGES BASED ON THE MARKET DEMAND}

In March 2018, the National Standard for Undergraduate Major Teaching Quality in General Institutions of Higher Learning (hereinafter referred to as the National Standard) was promulgated, which systematically elaborated the training objectives and core curriculum setting for Business English majors. On this basis, private colleges and universities should formulate corresponding curriculum system according to the specific school situation. To cultivate the compound application talents with a solid English basic skill, broad international vision, specialized international business knowledge and skills, the basic knowledge and theory of the related disciplines such as economics, management and law, a strong ability of intercultural communication and higher cultural accomplishment, a good use of English in the international environment in the fields of business, trade, management and finance, etc. 


\section{THE MAJOR MEASURES OF CURRICULUM SYSTEM REFORM}

\subsection{The Establishment Of The "Progressive And Modular" Course System}

The curriculum setting of business English major should be closely centered on the training objectives and requirements of the major, and based on this, it should complement and link with each other. The "progressive" course system is based on the foundation of English. Through a series of practical training courses and professional Business English courses, students can understand business knowledge in learning English, improve business skills and consolidate the foundation of English at the same time. "Modularization" is divided into language module, crossover module and business module. Through "progressive and modular" course, the ultimate purpose is the realization of "English + business" compound ability.

\subsubsection{The Importance Of Curriculum System}

Curriculum construction is the cornerstone of specialty construction. Whether a reasonable curriculum system can be constructed is directly related to whether students can meet the needs of society and enterprises. Combining with the trend of regional economic development, the cultivation should follow The National Standard for Business English Undergraduate Teaching Quality, on the basis of strengthening the students' language basic skill, adhering to the goal of talent cultivation and future professional development, with employment as the guidance, ability as the core, professional development for the principle.

It is focused on the teaching of language and knowledge skills for freshmen and sophomores, crosscultural business knowledge, skills teaching for juniors and seniors. The courses in training students' business literacy should be increased, such as An Introduction to International Marketing, Cross-border Trade and Ecommerce Practice, International Business Comprehensive Practice curriculum. At the same time, the professional training and practice teaching hours need to be increased.

\subsubsection{Modularization Of Skill Curriculum}

Private higher education is a form of education with application-oriented ability training as the main body [2]. Skill training is the main body of private higher education and the foundation of building practical teaching system. The practice teaching content of business English major is to set the course in modules, which is the concentrated embodiment of the scientific principle, systematic principle, ability cultivation principle and double certificate integration principle of course setting. Practical teaching courses can be divided into the following modules:

\subsubsection{General education module}

The module teaching is to cultivate students the basic professional ability, train the students' political thought, moral cultivation, cultural quality, modern operation, writing skills, psychological aspects of the basic qualities by social investigation and practice, computer skills training, and improve the ability of judgment, analysis, problem solving, self-study ability and knowledge migration ability.

\subsubsection{Basic Language Skills module}

This module is a language skill module for business English majors. The main practical courses include: pronunciation, listening and speaking, writing, reading and translation skills. Firstly, the basic language skills of business English talents should be cultivated and lay a solid language foundation.

\subsubsection{The practical module of professional application ability}

The practical module courses are designed to develop student's compound, applied qualities first. It is different from traditional curriculum for tool-type talent cultivation. These courses include: international commercial law, international trade theory and practice, marketing, etc. Order operator, foreign trade correspondence, business reading cultivate the ability to master the main business processes of private colleges, business law, marketing and foreign trade correspondence writing ability.

\subsubsection{Professional comprehensive practice module}

The module in the first place is to cultivate the students' language application ability and seek out the problem, solve the problem with innovative thinking and practical work ability, including the professional practice, graduation thesis, network autonomous learning, the extracurricular activities (English corner, English radio, English newspapers and magazines), social practice, all kinds of English contests, foreign guests reception, business translation (oral and written), trade fairs, practice base practice, etc.

\subsubsection{Centralization of practical training courses}

The curricula integration of theoretical courses is application-oriented. For the practical courses it will take a special training way. A week training will be arranged after the corresponding theory class. Closed training be conducted, guided by the syllabus set on the basis of the training program, organized by professional 
teachers. They make a special trip guidance with the diversification of teaching content and innovation. Flexible, open, diverse teaching methods and locations can be chosen in extracurricular activities, special training can be divided into audio-visual training, business English training, professional training of foreign trade, business English comprehensive training, etc. The centralized training mode fully embodies the cultivation of vocational ability.

\section{(6) Integration of courses and professional certificates}

According to the fusion principle of double certificates between business English professional talent training target and practical curriculum setting, the business English industry professional qualification examination is combined with practical Business English courses and support each other [3]. The content of the professional qualification certificate examination and the planned content are synchronized. In curriculum system, it is to host a variety of professional certification exams with the approval of the National Ministry of Labor and social authorities, such as the Business English certificate level 1, Export Agent, Customs Declaration, Merchandiser, Computer Grade certificate, Mandarin Level certificate, PETS exam certificate. The qualifications of all kinds of the skills are closely integrated with the daily teaching based on the concept "learning for practice and practice to promote learning. This concept provides guidance and training, so that the students can successfully pass the exam, which is conducive to the realization of the double-certificate communication, double-certificate "and" talent training objectives. It enhances students' employment competitiveness and reflects personal value, which is more conducive for the students to achieve zero distance on the job after the graduation.

\subsection{Integration Of Course And Certificates}

With the increasingly severe employment situation, how to improve students' employment competitiveness is an urgent problem for many colleges and majors. Certificate is an effective means to check whether talents are qualified or not. The acquisition of certificates is usually based on a fair and relatively scientific platform. At the same time, it promotes learning by taking exams. Students are bound to acquire or deepen relevant skills needed in the process of preparing for the certificates. Certificates are just like stepping stones to success, and also an important criterion for enterprises to select talents. Business English aims at cultivating "language + business" compound talents. Therefore, students majoring in business English should be encouraged to obtain at least three kinds of qualification certificates at school: (1) Pure language, such as TEM4/8; (2) Business language certificate, such as TBEM4/8; The BEC Vantage/Higher; (3) Pure Business certificates, such as cross-border e- commerce professional, marketing specialist, etc. Students can also choose to obtain other relevant professional certificates according to their interests, strengths and employment situation, such as translation certificate, teacher certification, etc. Three types of certificates in hand will greatly enhance the competitiveness of the students.

\subsection{The Promotion Of Learning And Teaching With Competition}

The teaching mode of "The promotion of learning and teaching with competition" is adopted in the form of project scheme to conduct a series of subjects or skills contest with specialized teachers' guidance. The competition and contests are closely integrated with the students' learning skills, comprehensive qualities [4]. To teach, learn, practice and compete are in harmony with each other, adhering to take the student as the main body, teacher as the leading factor. The ability to compete is especially important for Business English students. "To promote learning by contests" mode should be strongly advocated. Through the encouragement teachers organize students to participate in a series of related events, such as the CNP English Speaking, Writing, Reading Competition, the National Competition of Business English Translation, Crossborder Electricity Business Innovation Entrepreneurship Competition for Chinese college students, etc. The students are to be trained in a planned and long-term way. In the course of training and competition, students can master the corresponding knowledge and skills [5].

\subsection{School-enterprise Cooperation, Combination Of Courses And Posts}

School-enterprise cooperation, also known as the education based on the cooperation between the school and the enterprises, is accepted "cooperative education" in the international field. The explanation of "cooperative education" from the World Cooperative Education Association is, "Making good use of the two different educational environment and resources from the schools and enterprises, and combining the learning in the classroom and learning in the work together, really enable the students to apply their theoretical knowledge to practical operation.

The cooperation between Business English and enterprises is an important way to promote the sustainable, healthy and effective development of the major, and it is also an innovative entry point to help schools improve the quality of talent cultivation. In the era of Internet knowledge economy with rapid development, the education reform and curriculum setting should be market-oriented and adapt to the demand of popularization, which is the foundation of the application-oriented university education. Business 
English major should rely on the extravert economy of Hubei Province and take the emerging cross-border ecommerce as an opportunity to carry out various forms of school-enterprise cooperation with neighboring enterprises, which is the core direction of curriculum system reform in the new situation. School-enterprise cooperation is not only an important measure for the transformation and development of undergraduate colleges, but also an important way to cultivate Business English talents. The combination of courses and posts is an important way to achieve the goal of talent training.

In the process of school-enterprise cooperation, the school provides places for enterprises to select talents while the enterprise trains the talented person for the school, and provides the practical operation opportunity on the post [6].

\section{CONCLUSIONS}

Business English is a compound major with the typical characteristics of application. To cultivate the applied talents who learn English well and are proficient in business, it is necessary to stimulate students' learning enthusiasm from many aspects and cultivate students' practical ability. Therefore, "course, certificate, competition and post" can highly realize the combination of theory and practice, comprehensively improve students' self-learning ability and comprehensive professional qualities, deepen the reform of Business English teaching and the mode innovation of talent training, in order to make the Business English cultivation distinctive and effective.

\section{REFERENCES}

[1] L. F. Wang, R. Jie. Development and research status of business English textbooks in the past 70 years in China $[\mathrm{J}]$. Frontiers in foreign language education research. 2021, 4(02):43.

[2] Y. Xu, Exploration of Local Business English Curriculum [J]. Education Teaching Forum. 2019 (10): 125 .

[3] Z. Y. Hui, L. L. Zhao. Construction and Practice of Innovation Practice Course System for Business English Majors [J]. Overseas English. 2019(02): 123.

[4] Y. P. Zhou. Study on the Countermeasures of Training International Business English Talents in Private Colleges and Universities against the Background of "One Belt And One Road"[J]. Education Teaching Forum. 2019 (10): 37.

[5] L. Li, C. X. Lin. A Corpus-based Study of Common Business English Vocabularies [J]. Foreign Language Research. 2021(04): 64.
[6] L. F. Wang, C. Cui. On Paradigms and Methods of Interdisciplinary Research in Business English [J]. English World. 2019(02): 58. 